\title{
A NOTE ON THE DATE AND EDITIONS OF CALDERON'S DE UN CASTIGO, TRES VENGANZAS
}

Gary E. Bigelow

A careful reading of Calderón de la Barca's De un castigo, tres venganzas reveals that this play merits more than the very slight, and sometimes errant, attention which scholars have heretofore devoted to it. ${ }^{1}$. The purpose of the present study is to elucidate the problems concerning the date and editions of the play, and to suggest some solutions to those problems.

The lack of any precise allusion within the text to any datable contemporary event has made it impossible to determine with certainty the year of composition; nor has documentation relevant to the date of its first performance been discovered. According to Valbuena Briones, the play was published first in Parte diecinueve de Comedias de varios autores, and again in Parte veinte y ocho de Comedias de varios autores (Huesca, 1634). ${ }^{2}$ Valbuena's allusion to the Parte diecinueve is made without reference to the date or place of publication. The fact of the matter is that the Parte diecinueve does not exist as such; Valbuena is the only critic or bibliographer who cites it. An investigation of the edition cited of the Parte veinte y ocho reveals the source of the confusion: this collection (T/14818-46 in the Biblioteca Nacional in Madrid) consists of twenty-nine volumes, the nineteenth of which contains an undated edition of De un castigo, tres venganzas, attribuited to Calderón. The latter may be the same edition on which Cotarelo y Mori bases his suggestion that Un castigo en tres venganzas, as the title is often given, may first have been performed in 1633: "contiene una aprobación firmada a 27 de octubre de 1633." ${ }^{3}$ Citing Hartzenbusch, Schmidt indicates an earlier terminus ad quem for this edition of the Parte veinte $\mathbf{y}$ ocho, also said to have been published in Huesca in 1634, but licensed on April 3, 1633, in which the play appears with the title De un castigo, tres venganzas. ${ }^{4}$

It thus seems that Calderón must have written the play prior to April 3, 1633; but the question of how much earlier seems destined to find no easy answer. Cotarelo implies that a relatively short time may have transpired between the writing and the approval for publication of the work; nevertheless, he gives no firm evidence for this contention. In a previous edition of the Obras completas, Valbuena Briones stated: "Schmidt afirma que esta obra fue escrita hacia 1625 ó 1626. Nosotros aceptamos, sin embargo, como más fiel, la que señala el norteamericano Warren Hillborn, 1628, o quizá más tardía." 5 Without any explanation the reference to Hilborn is omitted from the corresponding passage of the subsequent edition, which reads as follows: "De un castigo, tres venganzas, es una obra temprana. Schmidt propone la fecha de 1625 ó 1626."

First, let us deal with the date Valbuena attributes to Schmidt, since he apparently has decided in favor of this opinion. Contrary to what Valbuena has written, 
Schmidt is not referring to Calderón's play when he mentions the years 1625 or 1626 ; rather, he speaks of De un castigo, dos venganzas, a play by Juan Pérez de Montalbán. ${ }^{7}$ In fact, Schmidt, on the basis of its style, attributes De un castigo, tres venganzas to the intermediate (not the early) period of Calderón's dramatic career. ${ }^{8}$ This view, though not expressed in terms of a specific year, might not differ greatly from the conclusion which Hilborn reaches by means of metrical comparison: "the versification indicates that it is improbable that its date is later than 1628."

Hilborn's assumption cannot, however, be accepted without serious reservations concerning the process by which he arrives at it. Strophic comparisons have been used with apparently great success in helping to date many plays of Lope de Vega, ${ }^{10}$ but as Courtney Bruerton points out in his review of Hilborn's book: "In striking contrast to the plays of Lope de Vega, few of Calderón's can be dated exactly." 1 Although generally he praises Hilborn's study, one of his criticisms of it concerns the play in question: "The author believes (p. 12) that Un castigo en tres venganzas belongs about 1628 because of its resemblance to Luis Pérez el Gallego, but we do not know with certainty that the latter play was written in 1628." 12 There are other criteria than this used by Hilborn to date the play, but a careful reading of his study seems to reveal a certain inconsistency in the application of these criteria. For example, Lances de amor $y$ fortuna (dated "c. 1624-25"1 3) has nearly the same strophic proportions as Peor está que estaba, which is definitely dated $1630 .{ }^{14}$ Though the author explains away the importance of the presence of quintillas and sextinas in the former, he stresses their supposedly decisive nature in Un castigo en tres venganzas. ${ }^{15}$ Another possible flaw may be found in the section dealing with plays definitely dated 1631-32. Hilborn states that the plays known to be of these years vary in their use of quintillas: none in El monstruo de la fortuna, ten lines in Mejor está que estaba, four percent in La puente de Mantible, six percent in La banda y la flor. The author says that "this contrasts with the almost total absence of this metre in the period 1625-28."16 If this is a key criterion for distinguishing such later plays from those of $1625-28$, it remains to be explained why the percentage of quintillas in $\mathrm{El}$ astrólogo fingido (4\%) and in Lances de amor y fortuna (5\%) did not exclude them from the $1625-28$ group. ${ }^{17}$ Hilborn himself expresses reservations concerning the impossibility of absolute certainty of dating by strophic comparisons. ${ }^{18}$ Because of all of these uncertainties, acceptance of 1628 as a more likely date of composition than perhaps even 1632 would not seem sufficiently warranted. For the time being, if seems necessary to bear with a certain degree of mystery concerning the date of De un castigo, tres venganzas.

Reference has already been made to the earliest known edition of the play: Parte veinte y ocho de Comedias de varios autores. ${ }^{19}$ Of course the comedia was not published in this collection with the approval or under the supervision of the author. In fact, none of the editions of this play published while Calderón was alive, or subsequently, had his authorization. ${ }^{20}$ Valbuena Briones cites, in addition to the aforementioned Parte, a suelta edition of $1637 .^{21}$ Several other single-play editions, possibly from the time of Calderón or shortly after, have survived until now; but, as Astrana Marín points out, at that time "casi todas las sueltas carecen de lugar y año de impresión." ${ }^{22}$ Such editions are usually listed as Un castigo en tres venganzas in Salvá, ${ }^{23}$ 
in the Biblioteca de la Real Academia Española, ${ }^{24}$ in the Library of the University of North Carolina, ${ }^{25}$ and in the Library of Congress, ${ }^{26}$ among others.

De un castigo, tres venganzas was apparently published in a collection of Comedias de Lope de Vega Carpio (y otros autores) Parte 28 (Zaragoza, 1639. La Barrera comments on this pirated edition: "Es una de ias llamadas extravagantes...Van atribuidas a Lope." 27

Another edition listed by La Barrera in which the play was collected is the "Quinta Parte de comedias de don Pedro Calderón de la Barca. - Barcelona, por Antonio La Caballería, año de 1677. (Es impresión de Madrid): $4^{\circ}$. Publicación furtiva, que rechazó Calderón. De las diez comedias que comprende, dos no son suyas. Carece de licencias." 28 Here the title is listed as Un castigo en tres venganzas. In a study of this edition, Astrana Marín clarifies some of the circumstances surrounding its publication. ${ }^{29} \mathrm{He}$ notes that there is a suspicious aprobación on the second page, but that even more dubious than this possibly counterfeit statement of approval is the tasa, which is dated not in Barcelona (as would seem natural), but in Madrid, March 18,1677. Four months later (if the dates are trustworthy) the second edition of the Quinta Parte was published in Madrid, "a costa de Antonio Francisco de Zafra, y dedicada por él a don Ínigo Melchor Fernández de Velasco." ${ }^{0}$ Just after the appearance of this edition (August, 1677), Calderón's edition of his Autos Sacramentales was published. In a prologue to the Autos, the author speaks out against the literary piracy which his works had suffered:

... pues no contenta la codicia con haber impreso tantos hurtados escritos mios como andan sin mi permiso, adocenados, y tantos como, sin ser míos, andan impresos con mi nombre, ha salido ahora un libro intitulado Quinta parte de comedias de Calderón con tantas falsedades como haberse impreso en Madrid y tener puesta su impresión en Barcelona, no tener licencia ni remisión ni del vicario ni del Consejo, ni aprobación de persona conocida. $Y$, finalmente, de diez comedias que contiene no ser las cuatro mías, ni aun ninguna pudiera decir, según están no cabales, adulteradas y defectuosas; bien como trasladadas a hurto para vendidas y compradas de quien no pudo comprarlas ni venderlas. ${ }^{31}$

As Astrana Marín notes, there were actually only two alien works falsely attributed to Calderón, not four. There are two others of which the titles had been so altered that the author did not recognize them as his. Although our play appeared as Un castigo en tres venganzas, this was not one of the disputed works.

A more recent critic has clarified still further the relationship between the two versions of the Quinta Parte, and has ventured an opinion as to their textual reliability. ${ }^{32}$ Calderón's rejection (quoted above) refers, according to D. W. Cruickshank, to only one of the two versions: the Barcelona imprint; for the Madrid version may well have appeared too late for Calderón to comment on it. ${ }^{33}$ Besides the printed dates and Calderón's allusion to $\mathrm{B}$, other evidence corroborates that $\mathrm{M}$ is a copy of $\mathrm{B}$ : in the fé de erratas of M, there is a reference to B. ${ }^{34}$ Although the first edition of the Quinta Parte was ostensibly published in Barcelona, typographical evidence indicates, states Cruickshank, that Calderón was correct in saying that it was printed in Madrid. ${ }^{35}$ That Zafra really did print $\mathrm{M}$ seems to be confirmed, too, by typographical comparison. ${ }^{36}$ 
Yet De un castigo, tres venganzas does not appear in the so-called Verdadera Quinta Parte de comedias de don Pedro Calderón de la Barca... published in 1682 in Madrid by Vera Tassis. ${ }^{37}$ Actually only two comedias from the "false" Quinta Parte are included in this, the first of the Vera Tassis partes to be printed. In the Verdadera Quinta Parte, Vera Tassis includes defective lists which purport to differentiate between the comedias verdaderas and the comedias supuestas; wrongly, he includes as supposititious El Tuzaní de la Alpujarra and Un castigo en tres venganzas, "que el mismo don Pedro denomina De un castigo, tres venganzas." 38 According to Astrana Marín, the friendship which Vera Tassis claimed for Calderón, as well as his supposed access to autograph manuscripts of his works, was challenged nearly immediately, and since has proven to be false. ${ }^{39}$ But as Cruickshank points out in another study, it is this opinion which is faulty: "Let his detractors say what they will, Vera Tassis was Calderón's friend. That the friendship was mutual is evident from the fact that Calderón wrote the aprobación for Vera's edition of the works of Agustín de Salazar y Torres, a friend of both men, and from the way in which Vera defended El galán fantasma from the censor in 1689, long after Calderón was dead." 40 Although by modern academic standards Vera's editorial methods may be criticized, he was following the accepted practice of his age, making additions and corrections as he saw fit. ${ }^{41}$

Two editions of Calderón's Nouena Parte were made by Vera Tassis, according to La Barrera, both published in Madrid: one in 1691, the other in $1698 .{ }^{42}$ In the editor's preface to the 1691 edition, he directs some very interesting, though not wholly trustworthy words to the reader: "La comedia de Amar después de la muerte ... la desconoció por suya don Pedro, no tanto por hallarla con el título de El Tuzaní de la Alpujarra, cuanto por verla adulterada y diminuta en la impresión. La de Un castigo en tres venganzas, que también está en la quinta falsa, padecía la misma calamidad, y por eso se anota allí, y aquí se publican, ambas, desmintiendo los errores de la prensa..." 33 What Vera Tassis says about Amar después de la muerte seems to ring true, according to what Calderón had written in the preface to his Autos; but not so, what the editor says of the other play. For it was he, not Calderón, who doubted that the author had written $\mathbf{D e}$ un castigo, tres venganzas; the two cases are different, and the errors are as much his as of the press.

Referring to the nine volumes of Calderón's works edited by Vera Tassis, Astrana Marín gives a concise summary of the major modern editions which followed: "Estos nueve volúmenes se reimprimieron muchas veces en los últimos años del siglo XVII y primera mitad del XVIII, y su texto pasó con escasas variantes a las ediciones del estrafalario Fernández de Apontes (1760), Keil (1827-30), Hartzenbusch (1848) y todas las colecciones que se han seguido." 44 Jaime Moll has shown that one of the reprints of the Vera Tassis volumes was done in $1763-67$ by Sapera and Suriá. ${ }^{45}$ It is the opinion of Cruickshank that some of these editions may be worthless in establishing a text: "Some texts can be rejected in their entirety, such as the second Vera Tassis edition of the plays, or the Apontes edition of the plays and autos. No editor will be helped to produce a better text by consultation of the readings of those editions." 46

Astrana Marín seems to imply that, because of his low esteem of Vera Tassis and his editions, none of the latter were used in preparing his own edition of the plays; rather, that he used the earliest text available to him (the Parte veinte y ocho). ${ }^{47}$ 
Although Valbuena Briones alleges in his two editions $(1959,1966)$ that he based both on the Parte diecinueve (shown above to be the nineteenth volume of the Parte veinte $y$ ocho), in a personal letter written in 1972 he suggests that two different sources were used. ${ }^{48}$ Variants in the texts of his two Aguilar editions lend credence to the belief that, in fact, two disparate editions may have been consulted. ${ }^{49}$ Hartzenbusch had introduced stage directions and indications concerning the place of the dramatic action, as well as many useless scene divisions. Astrana Marín and Valbuena Briones have rejected, rightly, the arbitrary and sometimes confusing scene divisions; but they have maintained the often useful stage directions and indications of place, which Hartzenbusch usually, according to Astrana Marín, "estableció con mucho tino."50

There seem to be few great textual problems in any of these recent editions of the play. Occasionally a line or so of poetry seems to be missing, and there a small number of apparently typographical errors. The only major variant is one which occurs in a speech by Federico, near the end of the play. Referring to the city where most of the action of the drama occurs, and which had been the scene of violent struggles against the Duque de Borgoña's enemies, he says: "En esta ciudad que inunda,/ más que con líquida plata, el gran Danubio con sangre/ de enemigos de tu infancia..." (Valbuena Briones, 5th ed., 1966, p. 64b). In several other editions, however, the river mentioned is the Ródano (Rhone): Valbuena Briones' fourth edition coincides with those of Hartzenbusch, BAE (Madrid: Hernando, 1910), XIV; and of Astrana Marín (ed. cit.), in naming the Ródano. What makes this strange is that Valbuena Briones' fifth edition coincides with the early editions of the play, all of which refer to the Danubio: Parte veinte y ocho de Comedias de varios autores (Huesca: Pedro Blusón, 1634), to be found in the Biblioteca Nacional in Madrid under the number T/14818-46; Quinta Parte de Comedias de don Pedro Calderón de la Barca (Barcelona: Antonio La Caballería, 1677), R/12589; Nouena Parte de Comedias... (Madrid: Juan García Infanzón, 1698), $\mathrm{T}-\mathrm{i} / 130 .^{51}$

All of the early editions consulted set the action in and near a city on the Danube. Why, then, should three modern editions, which the editors maintain have been based on those early ones, coincide in changing Danubio to Ródano? The answer centers on Hartzenbusch's editorial practices, and on the possible historical identity (or identities) of the drama's Duque Carlos de Borgoña. Astrana Marín and Valbuena Briones generally accepted Hartzenbusch's stage directions and settings; it is not unreasonable, therefore, to speculate that they may also have adopted his "correction" in textual content. ${ }^{52}$ They state that the action takes place in and near a city in Burgundy, no doubt basing their inference on the title of Carlos, Duque de Borgoña. Reference to a map of the Burgundian lands in 1477, the time of the reign of the historical Charles the Bold (also, the Rash), Duke of Burgundy, reveals that the Rhone (not the Danube) does flow through them. ${ }^{53}$ Believing the dramatic action to transpire in Burgundy, Hartzenbusch changed the text to reflect what he must have seen as greater geographical accuracy.

Although Charles the Bold's personal character and certain events of his reign may in part have inspired Calderón's Duke, a number of problems exist which militate against accepting such a premise without reservations. Among these doubts are the following: that the sobriquet of the historical Charles was "the Bold" or "the Rash," 
whereas in the play he is el justiciero; his enemies did not include the Duke of Saxony, but in the comedia his foe is el de Sajonia; and the Danube (the originally-mentioned river) flows through no part of Burgundy.

These three problems all point to another historical figure: Charles $\mathrm{V}$, who was also, in title, a Duke of Burgundy. Charles V (I of Spain) was known as a rey justiciero; one of his fiercest enemies was the Duke of Saxony; and the Empire's territories included a great part of the Danube. A direct descendent of Charles the Bold, Charles V was identified to a great extent with his Burgundian heritage. These facts are well-documented in numerous early histories of the Emperor. ${ }^{54}$ Because Charles V seems at least as likely a potential source of inspiration for Calderón as does Charles the Bold, there would seem to be no strong reason for accepting a city in Burgundy as the scene of the action of the play. Assuming that Danubio is correct, a good case can be made for Vienna, the city in which Charles $\mathrm{V}$ had been victorious twice in his career: once, against an internal rebellion; then again, against the Turkish invasion of Europe. ${ }^{55}$ In this instance Hartzenbusch (and those who followed his reading of the play) have been mistaken.

A number of problems and inconsistencies concerning the date and editions of De un castigo, tres venganzas have been brought to light here. Unfortunately, the limitations of this brief study have allowed but tentative solutions to some of the questions, and mere hints at the wealth of critical attention which this somewhat early, but mature, play deserves.

\section{University of Wisconsin-Green Bay}

\section{NOTES}

${ }^{1}$ This play is dealt with in my doctoral dissertation, done at the University of Pittsburgh:"De un castigo, tres venganzas and the Relationship of Justice and Vengeance in the Theater of Calderón: A Critical and Historical Study" (Ann Arbor: University Microfilms, 1974).

${ }^{2}$ Angel Valbuena Briones (ed.), Don Pedro Calderón de la Barca: Obras Completas. Quinta edición (Madrid: Aguilar, 1966), I, 36. Neither Simón Díaz, Bibliografia de la Literatura Hispánica (Madrid: C.S.I.C., 1965), IV, 200, nor D. Cayetano Alberto de La Barrera y Leirado, Catálogo Bibliográfico y Biográfico del Teatro Antiguo Español, Desde sus orígenes hasta mediados del siglo XVIII, facsimile of 1860 first edition (Madrid: Gredos, 1969), pp. 683-84, mention ever having seen this Parte diecinueve. It is alleged by Valbuena Briones, nevertheless, to be the source of his fifth edition.

${ }^{3}$ Emilio Cotarelo y Mori, Ensayo sobre la vida y obras de D. Pedro Calderón de la Barca (Madrid: Tip. de la "Rev. de arch., Bibl. y Museos," 1924), p. 149, adds that this Parte veinte y ocho was published by Pedro Blusón.

${ }^{4}$ F. W. V. Schmidt, Die Schauspiele Calderón's dargestellt und erläutert (Elberfeld: R. L. Friderichs, 1857), p. 512. The reason for there being two titles for supposedly the same edition of the same comedia is not clear. In Calderón's Nouena Parte de Comedias ... said to be edited by Vera Tassis in Madrid, 1691, however, an apparently parallel equivocation occurs: in the index, the play is listed as Un castigo en tres venganzas; but at the head of the text itself, it is De un castigo, tres venganzas ( $\mathrm{I}$ add the comma, as did Valbuena Briones, to standardize the punctuation.). This edition is catalogued under the number R 11353, vol. 9, in the Biblioteca Nacional. 
5 A. Valbuena Briones (ed.), Don Pedro Calderón de la Barca: Obras Completas, Cuarta edición (Madrid: Aguilar, 1959), I, 178.

${ }^{6}$ Valbuena Briones, 5th ed., I, 36.

${ }^{7}$ Schmidt, pp. 174-75.

${ }^{8}$ Schmidt, p. 174.

${ }^{9}$ Harry Warren Hilborn, Ph.D., A Chronology of the Plays of D. Pedro Calderón de la Barca (Toronto: The University of Toronto Press, 1938), p. 12.

${ }^{10} \mathrm{~S}$. Griswold Morley and Courtney Bruerton, Cronología de las comedias de Lope de Vega (Madrid: Gredos, 1968). Trans. María Rosa Cartes from the original English edition (New York, 1940).

11 Courtney Bruerton, review of A Chronology of the Plays of D. Pedro Calderón de la Barca by Harry Warren Hilborn, Ph.D. (Toronto, 1938) in Hispanic Review, VIII ( 1940), p. 267.

${ }^{12}$ Bruerton, p. 270. In a more recent article, N. D. Shergold and J. E. Varey, "Some Early Calderón Dates," BHS, XXXVIII (1961), p. 286, suggest for Luis Pérez el Gallego a date “... Before 21 Dec. 1929 (? 1628)."

${ }^{13}$ Hilborn, p. 10.

14 Hilborn, p. 13.

15 Hilborn, p. 12.

16 Hilborn, p. 16.

${ }^{17}$ Hilborn, pp. 9-10.

${ }^{18}$ Hilborn, p. v.

${ }^{19}$ La Barrera, p. 684, lists the comedias included in this Parte, along with the following bibliographical information: "En Huesca por Pedro Blusón, impressor de la Universidad, año de 1634. A costa de Pedro Escuer, mercader de libros; $4^{\circ}$. (contd.) Aprobación del doctor don Diego Amigo, en Zaragoza, á 27 de octubre de 1633."

${ }^{20}$ Luis Astrana Marín (ed.), Don Pedro Calderón de la Barca: Obras Completas: Textos íntegros según las primeras ediciones y los manuscritos autógrafos, Tomo I, Dramas (Madrid: Aguilar, 1951), pp. 44-45, reproduces the "Memoria de Comedias" which Calderón sent to the Duque de Veragua on June 24,1680 , enumerating the plays which he recognized as his. The list is divided into four volumes which correspond to the four Partes of which he had authorized publication. De un castigo, tres venganzas appears in a separate section: "Los restantes obras de la lista son las no coleccionadas autorizadamente y hasta entonces inéditas" (p. 45).

${ }^{21}$ Valbuena Briones, 5th ed., I, 36. He indicates that he found this edition in the Ticknor Collection in Boston, Massachusetts.

22 Astrana Marín, I, 13.

23 D. Pedro Salvá y Mallén, Catálogo de la Biblioteca de Salvá (Valencia: Imprenta de Ferrer de Orga, 1872), I, 587.

24 "Catálogo de comedias sueltas conservadas en la Biblioteca de la Real Academia Española," BRAE, XLVI (1966), p. 134.

25 William A. Knight with Mabel Barrett Jones, A Catalogue of Comedias Sueltas in the Library of the University of North Carolina (Chapel Hill: University of North Carolina Library, 1965), pp. 219-20.

${ }^{26}$ The National Union Catalog Pre-1956 Imprints (London: Mansell, 1971), vol. 89, p. 476.

${ }^{27}$ La Barrera, p. 54a.

${ }^{28}$ La Barrera, p. 54a.

${ }^{29}$ Astrana Marín, pp. 30ff. 
31 Quoted by Astrana Marín, p. 31b.

32 D. W. Cruickshank, "The two editions of Calderón's Quinta Parte (1677)," in vol. I, The Textual Criticism of Calderón's Comedias in Pedro Calderón de la Barca Comedias, a facsimile edition prepared by D. W. Cruickshank and J. E. Varey (London: Gregg Intl. Publishers Ltd. with Támesis Books Ltd., 1973), pp. 201-10.

${ }^{33}$ D. W. Cruicdshank, p. 204.

34 D. W. Cruickshank, p. 205.

35 D. W. Cruickshank, pp. 206-07, ventures to suggest that the Madrid printer Bernardo de Hervada might have been involved in printing part of B; and that Melchor Sánchez almost certainly printed most of $\mathbf{B}$.

36 D. W. Cruickshand, p. 208.

37 La Barrera, p. 52.

38 Astrana Marín, p. 36.

39 Astrana Marín, pp. 39-40, cites the challenges to Vera Tassis' statements, made by don Gaspar Agustín de Lara, who ". . . asqueado de las mentiras de Vera Tassis, publicó un extraño Obelisco fúnebre, pirámide funesta que construía a la inmortal memoria de don Pedro Calderón de la Barca . . . (Madrid, 1684)."

40 D. W. Cruickshank, "The Textual Criticism of Calderón's Comedias: A Survey," in Vol. I, ed. cit., pp. 1-35, esp. p. 12.

41 D. W. Cruickshank, pp. 12-14, notes this and the dates of the first editions of the Vera Tassis partes of Calderón, which are as follows: Verdadera quinta parte, 1682; Sexta parte, 1683; Séptima parte, 1683; Octava parte, 1684. Then the four partes edited under Calderón's supervision much earlier were re-edited: Primera parte, 1685; Segunda parte, 1686; Tercera parte, 1687. Finally the Novena parte appeared in 1691; the projected Décima parte never did.

42 La Barrera, p. 53 . See also note 51 , below.

43 Quoted from Vera Tassis by Astrana Marín, p. 47.

44 Astrana Marín, p. 48. These editions are listed in detail in the National Union Catalog (see note 26), pp. $470 \mathrm{ff}$.

45 Jaime Moll, "Las nueve partes de Calderón editadas en comedias sueltas," BRAE, LI (1971), pp. 259-304.

${ }^{46}$ D. W. Cruickshank, p. 34.

47 Astrana Marín, p. 51a. Whether Astrana Marín really did base his Aguilar edition (including De un castigo, tres venganzas) on the Parte veinte y ocho is open to some question, as will be explained below.

48 In a personal communication to Professor Gonzalo Sobejano in 1972, Valbuena Briones very tentatively states that he used either a suelta or a Vera Tassis edition for his fourth edition, and the apochryphal Parte diecinueve for his fifth.

49 See the explanation of the variant below.

50 Astrana Marín, p. 52.

51 The latter is the second edition of the Nouena Parte. Danubio is also the variant in Nouena Parte de Comedias... (Madrid: Alvarez Baena, 1691), R/11353 (vol. 9); but Cruickshank notes (p. 17) that this and the other eight volumes of the series $\mathrm{R} / 11345-53$ are fake editions, made by binding together sueltas, and they are not edited by Vera Tassis (contrary to what they indicate). Cruickshank also gives other locations of the two authentic versions of the Quinta Parte (p. 41), and of certain other rare partes (pp. 38-43). 
52 This variant, introduced by Hartzenbusch, is adopted in turn by Astrana Marín and by Valbuena Briones (until his fifth edition); this gives a hint of doubt to the allegations of these two editors concerning which earlier editions of this play formed the bases for their own.

${ }^{53}$ Samuel Kinser (ed.), The Memoirs of Philippe de Commynes, trans. Isabelle Cazeaux (Columbia: University of South Carolina Press, 1969), includes a "Map of Western Europe in 1477." The Memoirs are among a number of early histories which dealt with Charles the Bold, and which are treated in my dissertation (see note 1, above). I have speculated that part of the dramatic action might have beer based on this historical figure.

54 Carlos Clavería, « Le Chevalier Délibéré 》 de Olivier de la Marche y sus versiones españolas del siglo XVI (Zaragoza: Institución "Fernando el Católico" C.S.I.C., 1950), pp. 38ff., also shows that this identification was neither superficial nor ephemeral, as is borne out by the early histories of Charles V, investigated in my dissertation.

55 Fray Prudencio de Sandoval, Historia de la vida y hechos del Empregador Carlos V ..., ed. Carlos Seco Serrano (Madrid: Hernando, 1955), BAE vols. 80 (I), 81 (II), 82 (III): I, 158-60; II, 436. 